\title{
Study on Rural Tourism Product Development in Xi'an Section of Northern Foot of Qinling Mountains from the Perspective of Experience
}

\author{
Lihui Qiu \\ School of Historical Culture and Tourism \\ Xi'an University \\ Xi'an, China 710065 \\ Kunsheng Zhang \\ School of Historical Culture and Tourism \\ Xi'an University \\ Xi'an, China 710065
}

\author{
Xiaonan Zhang \\ Higher Vocational College \\ Xi'an Eurasia University \\ Xi'an, China 710065 \\ Zeyu $\mathrm{He}$ \\ School of Historical Culture and Tourism \\ Xi'an University \\ Xi'an, China 710065
}

\begin{abstract}
With the advent of experience economy, tourists are paying more and more attention to the experience and participatory in the process of tourism, thus putting forward higher requirements for rural tourism products. From the perspective of the development of rural tourism in China, experiential tourism products have begun to take shape, such as picking and fishing. However, from the perspective of demand, the experiential products of rural tourism still do not meet the needs of tourists' diversified and deep experience. This paper analyzes the problems of rural tourism products such as food, accommodation, tourism and entertainment in Xi'an Section of northern foot of Qinling Mountains. From the perspective of experience, we design the experiential rural tourism product in Xi'an Section of northern foot of Qinling Mountains, which provides a reference for the sustainable development of rural tourism in Xi'an.
\end{abstract}

Keywords-the northern foot of Qinling Mountain; visual angle of experience; rural tourism products

\section{INTRODUCTION}

According to the statistics of National Tourism Administration, there were 2.5 billion tourists in rural tourism in China in 2017. The scale of tourism consumption is over 1.4 trillion Yuan, and rural tourism has become one of the main ways of residents' leisure and vacation in China. Many scholars have paid attention to and studied it [1-5]. The rural tourism represented by rural, pastoral and folk customs, can meet the needs of leisure tourism of urban residents to return to nature, which is a yearning for people to "distant place". With the advent of experience economy, as the rich experience of tourism and the maturity of tourism concept, the traditional rural tourism has been unable to meet the diverse needs of tourists. This paper analyzes the problems of rural tourism products such as food, accommodation, tourism and entertainment in Xi'an Section of northern foot of Qinling Mountains. Based on the tourism resource in Xi'an Section of northern foot of Qinling Mountains, we design the development of experiential rural tourism product, which provides a reference for the sustainable development of rural tourism in Xi'an.

\section{RESEARCH METHODS}

In this paper, questionnaires and field surveys are adopted to investigate the experiential rural tourism products in the Xi'an Section of northern foot of Qinling Mountain. The questionnaire covers six aspects: diet, accommodation, environment, transportation, cultural atmosphere and entertainment facilities. In 2016 and 2017, the investigation team distributed a total of 295 questionnaires to tourists and local residents in a random way in three times, in some rural tourism areas in Xi'an, such as the Dong Han village, Yi Yi District, Languan Town, Lantian County, Xiangyu Ditch and Tangyu Town. And 295 copies were collected. The recovery rate was $100 \%$, with the effective questionnaires of 283 and the effective rate of $95.9 \%$. The data obtained from the questionnaire were collected, analyzed and statistically analyzed by Excel. At the same time, we made communications and visits to the businessmen in the investigation place who are operating rural tourism.

\section{RURAL TOURISM OVERVIEW OF XI'AN SECTION OF NORTHERN FOOT OF QINLING MOUNTAIN}

Xi'an Section of northern foot of Qinling Mountain is 166 $\mathrm{km}$ in length, with an area of $6000 \mathrm{~km} 2$. Except for Lianhu, Xincheng and Yanta in the state of urbanization, most of the other 7 districts and 2 counties are mainly rural structures, with rich rural tourism resources. By the end of 2016, Xi'an Section of northern foot of Qinling Mountain has owned 19 national A-level agritourism scenic spots, and 20 village hotels, village post houses and village inns. There are more than 4600 households operating agritainment and more than 200 leisure 
agricultural sightseeing parks. From the end of January 2016 to the end of October, the city's rural tourism received 67.8 million tourists, and its operating income was 4.98 billion Yuan.

With more than ten years of continuous development, the rural tourism products in the Xi'an Section of northern foot of Qinling Mountain are mainly "agritainment". During the development, "agritainment" rural tourism products has been gradually standardized, service quality has been constantly improving, and publicity efforts are being strengthened every year. Tourists' recognition of "agritainment" in the Xi'an Section of northern foot of Qinling Mountains is getting higher and higher. At present, there are mainly four kinds of rural tourism products in the Xi'an Section of northern foot of Qinling Mountains. First, the rural tourism products are centered on the folk art of Donghan Village, Huxian County. The "agritainment" in the East Han village is centered on farmer paintings. When the tourists watch farmers' paintings, they eat country style food and live in farmhouses, experiencing farmers' fun and experiencing changes in new countryside. Second, the rural tourism products are centered on the rural landscape in Languan Town, Lantian County. The "agritainment" in Languan Town is mainly enjoying the countryside, as well as angling, spring outing, eating farmhouse meal, living in farmhouses and enjoying the rural life. Third, the rural tourism products depend on historic sites of Xiangyu Ravine. The "agritainment" of Xiangyu Ravine is based on Changning Palace. While tourists visit Changning Palace, they can feel the life of farmers and experience the fashionable new countryside. Fourth, the rural tourism products are centered on the rural leisure medical care of Tangyu Town Agritainment. We can see the Tangyu Lake and take a bath in hot spring, enjoying the beautiful scenery and experiencing the healthy life. From the perspective of experience, the above four types of tourism products rely on simple perceptual experience, mainly attracting tourists through visual effects. During the tour, the participation of tourists is very low, which does not enable tourists to get higher level of psychological satisfaction.

\section{PROBLEMS IN DEVELOPMENT OF RURAL TOURISM PRODUCTS}

As can be seen from Table I, visitors have the highest satisfaction with the environment, indicating that the environment in Xi'an Section of northern foot of Qinling Mountains is very good. In addition, the satisfaction of other items such as diet and accommodation is relatively low and needs further improvement. From the perspective of experience, there are some problems in rural tourism products such as accommodation, food, tourism and entertainment in the villages of northern foot of Qinling Mountains.

TABLE I. TOURISTS' SATISFACTION WITH XI 'AN RURAL TOURISM ProdUCtS

\begin{tabular}{|l|l|l|l|l|l|l|}
\hline \multicolumn{1}{|c|}{ Evaluation items } & \multicolumn{1}{|c|}{ Diet } & \multicolumn{1}{c|}{ Accommodation } & \multicolumn{1}{c|}{ Environment } & \multicolumn{1}{c|}{ Transportation } & Cultural environment & Recreational facilities \\
\hline Satisfied & $20.30 \%$ & $8.70 \%$ & $75.00 \%$ & $30.20 \%$ & $19.20 \%$ & $22.70 \%$ \\
\hline Common & $69.20 \%$ & $80.80 \%$ & $22.10 \%$ & $50.00 \%$ & $63.40 \%$ & $49.40 \%$ \\
\hline Not satisfied & $10.50 \%$ & $10.50 \%$ & $2.90 \%$ & $19.80 \%$ & $17.40 \%$ & $27.90 \%$ \\
\hline
\end{tabular}

\section{A. Problems in "Accommodation"}

It can be found in the survey that tourists' satisfaction with accommodation was only $8.7 \% .80 .7 \%$ of the tourists felt hat the accommodation condition is general, and $10.5 \%$ of the tourists were not satisfied with the local accommodation. It can be seen from this that tourists have low satisfaction with accommodation in Xi 'an Section of the north foot of Qinling mountains. This can be confirmed from the interview and investigation. It can be seen on the spot visits that many of the "agritainment" accommodation facilities in the Xi'an Section of northern foot of Qinling Mountains were in poor health. The building is not in harmony with the surrounding natural environment, which does not reflect the rural atmosphere. And the infrastructural facilities are not sound enough. These problems seriously affect the tourist experience of tourists. Many tourists have been less satisfied with the rural tourism in the Xi'an Section of northern foot of Qinling Mountains.

\section{B. Problems in "Food"}

Only $20.3 \%$ of tourists are satisfied the local food of the agritainment. $69.2 \%$ of the tourists think the food is diet, and $10.5 \%$ of the tourists are not satisfied with the local diet. This shows that local tourism products in the aspect of "food" cannot satisfy the needs of tourists to experience the rural diet. One of the purposes of most tourists to rural tourism is to taste authentic farm food. It is required that the dishes are fresh and pollution-free and have the local flavor while eating. However, it is not satisfactory in the situation of several agritainment in Xi'an Section of northern foot of Qinling Mountains. Many of the ingredients used in agritainment are purchased from the surrounding towns, not the pollution-free vegetables grown on their own. The dishes also lack local flavor, so that tourists can not feel the local diet culture while eating.

\section{Problems in "Travel"}

The important part of displaying the characteristics of rural tourism is "travel", which is the core of rural tourism. However, according to the survey results, $19.8 \%$ of tourists are not satisfied with local traffic, and $17.4 \%$ of tourists are not satisfied with the local cultural atmosphere. This shows that the "travel" in the Xi'an Section of northern foot of Qinling Mountains cannot satisfy the tourists' experience needs. On the one hand, the main line of northern foot of Qinling Mountains is convenient, but the traffic condition accessed to various villages needs to be improved. On the other hand, there is a serious homogeneity phenomenon in the rural tourism products of the Xi'an section of northern foot of Qinling Mountains, which is almost the same, and does not consider the needs of tourists. For the tourists coming to the Xi'an section of northern foot of Qinling Mountains, their main purpose of rural tourism is to stay away from the noise of the 
city, put into the embrace of nature, alleviate the pressure of life, and feel the atmosphere of local environment. From the above survey, it can be seen that the development of rural tourism products in the Xi'an Section of northern foot of Qinling Mountains has been not fully taken into account with the individualized experience demand of tourists, which cause the uniformity of rural tourism products. If the "travel" connotation in the Xi'an Section of northern foot of Qinling Mountains is not enhanced, its development will be blocked.

\section{Problems in "Amusement"}

In rural tourism, the most direct experience is entertainment, which is also an essential part of rural tourism. It can be seen from Table I that only $22.7 \%$ of tourists are satisfied with entertainment facilities, and $27.9 \%$ of tourists are not satisfied with the local entertainment facilities, indicating that the rural tourism in the Xi'an Section of northern foot of Qinling Mountains cannot meet the needs of tourists in the aspect of "amusement". It is found in the survey that tourists want to participate in activities such as rafting, rock climbing, bungee jumping, adventure, fishing, rowing and picking. However, most of Xi'an Section of northern foot of Qinling Mountains has no relevant activities. Only a few items of rafting, fishing and rowing were found. For climbing, exploring and picking, these activities are very few and cannot meet the needs of tourists.

\section{DESIGN OF NEW PRODUCTS OF EXPERIENCING RURAL TOURISM}

The above analysis shows that there are many problems in the rural tourism products in Xi'an Section of northern foot of Qinling Mountains. In order to further enrich the connotation of rural tourism products and meet the needs of tourists in rural tourism, from the perspective of tourist experience, the original rural tourism products are reformed, and the tourist attractions in the northern foot of Qinling Mountains are innovated in structures according to the experience-type tourism product structure (Table II).So that new products for rural tourism [6-8] can be designed.

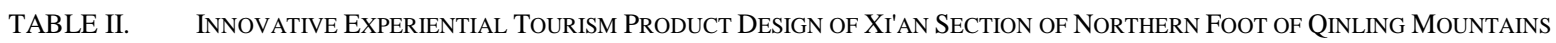

\begin{tabular}{|c|c|c|}
\hline $\begin{array}{c}\text { Design } \\
\text { Type }\end{array}$ & Product Name & Description \\
\hline \multirow[t]{3}{*}{$\begin{array}{l}\text { Entertainm } \\
\text { ent type }\end{array}$} & $\begin{array}{lr}\text { Rural } & \text { farming } \\
\text { DIY } & \text { leisure } \\
\text { travel } & \end{array}$ & $\begin{array}{l}\text { The traditional farming activities such as planting, farming, feeding and grain processing are carried out by tourists } \\
\text { themselves and the original agricultural activities can also be innovated according to their own ideas. Tourists can } \\
\text { participate in and experience the labor process and feel the joy of rural life. }\end{array}$ \\
\hline & $\begin{array}{l}\text { Production } \\
\text { experience tour } \\
\text { of country green } \\
\text { food }\end{array}$ & $\begin{array}{l}\text { All the ingredients are grown in rural farmland, without chemical fertilizers and pesticides, which ensures that the } \\
\text { ingredients are green and pollution-free. Tourists can obtain materials from local sources, and make and eat the local } \\
\text { traditional food under the guidance of the local people with experience in food production or do it by themselves. The } \\
\text { delicious foods include the pot helmet with Chinese characteristics, Liang Pi and pasta. }\end{array}$ \\
\hline & $\begin{array}{l}\text { Country } \\
\text { outdoor sports } \\
\text { tour }\end{array}$ & $\begin{array}{l}\text { It is mainly for young and middle-aged market, with outdoor sports as main. The mountains, waters and vegetation in the } \\
\text { northern foot of Qinling Mountains provide good natural conditions for outdoor sports activities, such as skiing, skiing, rock } \\
\text { climbing, drifting, simulated field combat and field training, so as to meet the psychological needs of young and middle- } \\
\text { aged tourists seeking to stimulate and pursue challenges. }\end{array}$ \\
\hline $\begin{array}{l}\text { Ducation } \\
\text { type }\end{array}$ & $\begin{array}{l}\text { Qinling } \\
\text { geological } \\
\text { survey tour } \\
\text { Qinling } \\
\text { archaeological } \\
\text { and cultural tour }\end{array}$ & $\begin{array}{l}\text { Qinling Mountains is rich in topography and geomorphology, complex in its geological structure, and is rich in geological } \\
\text { examination tourism resources. Taking young students, scientific workers and geoscience lovers as the target market, we } \\
\text { will develop the geological examination tourism resources in the Xi'an Section of northern foot of Qinling Mountains. } \\
\text { "Xi'an has always been an ancient imperial state since ancient times", Xi'an has a long history and culture, surrounded by } \\
\text { numerous emperors and mausoleas. Xi'an Section of northern foot of Qinling Mountains is highly valued for archaeological } \\
\text { and historical studies. This kind of tourism activities can be carried out on the basis of artistic performances, scene } \\
\text { reappearance and on-the-spot investigation, so that tourists can feel the local history and culture. }\end{array}$ \\
\hline \multirow[t]{2}{*}{$\begin{array}{l}\text { Avoidant } \\
\text { type }\end{array}$} & $\begin{array}{l}\text { Qinling retreat } \\
\text { experience tour }\end{array}$ & $\begin{array}{l}\text { Since ancient times, Qinling Mountains has been a sacred place for many hermits to retire from the world. There are } 72 \\
\text { Valley such excellent environment for seclusion, which make tourists live in noisy cities experience the seclusion of pastoral } \\
\text { life, which is composed of sunrise and sunset. }\end{array}$ \\
\hline & $\begin{array}{l}\text { Qinling health } \\
\text { care tour }\end{array}$ & $\begin{array}{l}\text { Qinling Mountains has } 3,210 \text { natural medicinal plants in the Shaanxi area, which can be taken locally. And some } \\
\text { rehabilitation convalescent bases and resorts can be built in villages with good ecological environment. We can excavate } \\
\text { local traditional Chinese medicine culture and longevity diet culture, and create tourism products such as health preserving, } \\
\text { diet health care and holiday recuperation. }\end{array}$ \\
\hline $\begin{array}{l}\text { Aesthetic } \\
\text { type }\end{array}$ & $\begin{array}{l}\text { Qinling } \\
\text { sketching } \\
\text { photography } \\
\text { tour }\end{array}$ & $\begin{array}{l}\text { Simple rural landscapes, Qinling Mountains's rich landscapes, animal and plant landscapes are good resources for sketching } \\
\text { and photography. Facing art learners, artists and photographers, it is necessary to develop sketching photography special } \\
\text { tourism products in the northern foot of Qinling Mountains. }\end{array}$ \\
\hline
\end{tabular}

\section{A. Recreational Rural Tourism Products}

Recreational rural tourism products are mainly leisure and entertainment, in which the tourists experience the rural living environment and the fun of life from a series of rural farming activities, rural food production, rural outdoor sports and other tourist products to meet the needs of the tourists to the rural life. This article mainly designs some experiential tourism products, such as rural tourism DIY leisure travel, rural green food production experience tour, rural outdoor sports tourism and other. Among them, rural farming DIY leisure tour and rural green food production experience tour are suitable for being developed in villages with large farmland and small population density, such as Languan Town, Lantian County which is surrounded by a large area of farmland and a small population, suitable for such tourism activities. Outdoor sports in rural areas need outdoor sports venues. In particular, rock climbing, skiing, skiing and rafting have high requirements for natural environment. And rock climbing depends on a cliff or a steep mountain. Skiing depends on the hillside or sloping land 
at higher altitude; grass skiing depends on the grasslands; rafting depends on more turbulent rivers. Only when these outdoor sports conditions are available can such tourism activities be carried out.

\section{B. Educational Rural Tourism Products}

Educational rural tourism products mainly rely on the rural natural environment with the value of scientific research and rural tourism areas with historical and cultural values, which mainly make the tourist experience have the unique regional natural environment and historical culture. It has a strong educational color; the Qinling Mountain geological examination tour and Qinling Mountain archaeological cultural tour are designed. Such tourism products must rely on certain natural geographical phenomena or historical and cultural relics. If the village near Changning Palace has certain historical and cultural accumulation, it can be developed with an archaeological culture tour.

\section{Evasive Rural Tourism Products}

Evasive tourism products are aimed at tourists who are tired of living environment and yearning for rural life. Tourists who need quiet rural living environment to adjust their body and mind or for convalesce are also the target market of evasive tourism products. This type of rural tourism product has very high requirements for the environment. Take the design of Qinling Mountains experience tour as an example, since it is the experience of seclusion, the region must be relatively closed with less modern elements. 72 Valley of Qinling Mountains is beautiful and natural, near the mountain and by the river, which is suitable for developing such tourism products.

\section{Aesthetic Rural Tourism Products}

The aesthetics in rural tourism is different from other aesthetics, which is not an aesthetic appreciation of grandeur, but is popular. The object of aesthetic appreciation is often the rural cultural landscape or natural landscape. Although its popularity is not high, this landscape must have its own unique beauty. So the products depend on the unique rural scenery. Qinling Mountains is located in the north-south boundary of China. Its natural geographical environment and cultural environment are different from other parts of the country. Qinling Mountains' plain rural landscape, rich landscape, animal and plant landscapes are good resources for sketching and photography. Facing art learners, artists and photographers as the target market, it is necessary to provide the necessary infrastructure, equipment and guidance, so as to develop special tourism products such as sketching and photography in Qinling Mountains.

\section{CONCLUSION}

With the coming of experience economy, experience and participation of tourists in the process of tourism activity are increasingly appreciated, which result in higher requirements on development of the rural tourism products. However, these rural tourism products developed early has been unable to cater for the diverse demand of tourism experience and the objective requirement of the rural development in present. The rural tourism development in northern foot of Qinling mountains necessarily take consideration of local tourism resources, fully explore local cultural characteristics and upgrade the early tourism products, forming unique, diverse and rich experiencing tourism products. The rural tourism development need integrate into local economic, ecological and sociocultural development, and propose new development pattern with diversification, characterization and multiindustrial integration.

\section{REFERENCES}

[1] Liu Deqian. Analysis of Rural Tourism, Agricultural Tourism and Folklore Tourism [J]. Tourism Tribune, Issue 3 of 2006.

[2] Luo Mingyi. Characteristics and Patterns of Rural Tourism Development in Yunnan Province [J]. Tourism Tribune, Issue 5 of 2006.

[3] Wang Yuling, Wang Huiping, Gui Kai. Research on Tourism Development of "Agriculture, Rural Areas and Farmers" Resources -Based on The Perspective of Rural Tourism Products [J]. Chinese Agricultural Science Bulletin, Issue 11 of 2013.

[4] Wang Huijuan. Leisure Agriculture and Rural Tourism Product Structure in Hebei [J]. Journal of Hebei University (philosophy and social science), Issue 5 of 2014.

[5] Guo Ling, Wang Zhizhang. Rural Tourism Development and Cultural Space Production_Based on the Case Study of Hongsha Village in Sansheng Town [J]. Social Scientist, Issue 4 of 2014.

[6] Xu Jian. Experience Tourism Product Development Strategy in the Era of Experience Economy[J]. Resource Environment and Development [J]. Resource Environment and Development, Issue 2 of 2010.

[7] Liao Guangping. Inheritance and Development of Farming Culture in Development of Rural Tourism [J]. Agricultural Economics, Issue 8 of 2014.

[8] Xu Li, Zheng Yahui, Liu Ju. Protection and Utilization of Rural Landscape Resources in the Development of Fishing Villages in Jiaodong [J]. Journal of Shandong Agricultural University (science edition), Issue 1 of 2014. 